\title{
Violence, post-conflict and electoral trends in Colombia: notes for reflection
}

\section{Violencia, posconflicto armado y comportamiento electoral en Colombia: notas para la reflexión}

\author{
Jerónimo Ríos (D)
}

Universidad Complutense de Madrid jeronimo.rios@ucm.es

\section{Jennifer Morales Correa (DD}

Universidad EAN

jmorales4159@universidadean.edu.co

\begin{abstract}
This descriptive exercise presented in this paper suggests a certain spatial relationship between regions in Colombia that for years had the highest levels of territorial vulnerability, in terms of exposure to the internal armed conflict and structural violence, and the predominant views expressed both during the FARC-EP plebiscite and the secondround presidential elections that took place in 2018. In a similar vein to the field of study of electoral geography, the reflections posited here suggest inquiring about a possible voting for peace trend in Colombia, which is particularly perceptible in the country's territorial periphery, where support for Gustavo Petro and backing for the Peace Agreement signed with the FARC-EP guerrillas have found more supporters.
\end{abstract}

Key Words: Colombian armed conflict, Peace Agreement, FARC-EP, electoral geography.

\section{Resumen}

El trabajo que se presenta a continuación, en un ejercicio descriptivo, sugiere una cierta relación espacial entre los lugares de Colombia que durante años presentaron mayores niveles de vulnerabilidad territorial, en términos derivados del conflicto armado interno y violencia estructural, con respecto a la posición predominante tanto a tenor del plebiscito con las FARC-EP, como con las elecciones presidenciales de la segunda vuelta, acontecidas en 2018. Con una alta proximidad al campo de estudio que representa la geografia electoral, se proponen reflexiones que sugeririan indagar en un posible voting for peace en Colombia, especialmente perceptible en la periferia territorial del país, en donde el apoyo a Gustavo Petro y el respaldo al Acuerdo de Paz suscrito con la guerrilla de las FARC-EP encuentra mayores adeptos.

Palabras Clave: Conflicto armado colombiano, Acuerdo de Paz, FARC-EP, geografía electoral.

Articulo: Recibido el 15 de noviembre de 2018 y aprobado el 26 de noviembre de 2018

\section{Cómo citar este articulo}

Ríos, J. \& Morales-Correa, J. (2019). Violence, the post-conflict and electoral trends in Colombia: notes for reflection, Reflexión Politica 21(41), pp. 8-19. DOI: https://doi.org/10.29375/01240781.3436 


\section{Introduction}

The main purpose of this article is to comment and reflect upon the relationship between violence, the post-conflict and electoral trends in Colombia, on the basis of certain patterns suggested by voter distribution maps in recent events: signing of the Peace Agreement, plebiscite vote on the agreement, and presidential elections.

The 2015 map of the areas with highest territorial vulnerability indicators in terms of direct violence derived from the armed conflict per se, and also socioeconomic structural violence (Galtung, 1969), displays a high level of correlation with the political and electoral behavior of these territories, both on October 2, 2016, the date of the plebiscite that asked the Colombian civil population to vote for or against the Peace Agreement signed one week earlier with the FARC-EP guerrilla, and with the tendency to vote in favor of presidential candidate Gustavo Petro. To put it in simpler terms: there seems to be a high level of correlation between direct violence, structural violence, support for the Peace Agreement and support for the progressive presidential candidate in the territories.

The aim of this article is to reflect on the possible existence of a vote for peace in Colombia, framing the topic with the specialized literature on the relationship between political behavior and electoral geography in general, and with regard to the Colombian case in particular.

The structure of this paper is particularly simple. First, it presents a review of the most relevant literature and the predominant theoretical approaches to the subject. Then it analyzes the spatial trends of the political behavior through three maps: the 2015 territorial vulnerability index map, the electoral behavior map of the October 2, 2016 plebiscite, and finally, the map for the second-round vote of the 2018 presidential elections. The paper will finalize with some conclusions aimed at opening possible lines of research and subsequent work to that regard which could determine whether it is really possible to understand an electoral motivation in Colombia whose fundamental cleavage is support for a Peace Agreement and a structural transformation of the dynamics that for decades have supported violence.

\section{State of the Art}

While this work centers on strictly descriptive aspects, the initial intention, in the absence of empirical evidence and more solid contributions to that regard, points to thinking about the possible correspondence between the experience of violence, the desire for peace, and the rupture with the particular way of understanding the resolution to this question, which has been posed by Uribismo since the beginning of the last decade. Contributions from Bussi (1998) to Sonnleitner (2013) give a good account of how the sum of cartographic methodologies and historical trends in electoral analysis provide particular readings of how the context and the place affect the particular way in which the citizenry internalizes, problematizes and politicizes the aspects that define and modulate their needs as citizens and their responses to public policy (Agnew, 1987; Lois, 2010).

Electoral geography provides multiple options for assessing the relationship between violence, peace and electoral support, ranging from viewing the constituencies themselves to addressing spatial variations in the vote distribution, in parallel to the violence derived from the conflict, the influence of environmental factors on electoral behavior, or the scope and meaning of electoral distribution and elements of local power that configure it (Johnston et al., 1987). The above does not exclude possible sociological analysis of the vote, in line with the proposal made by Goguel (1951) decades ago under a mosaic of qualitative or quantitative techniques that address the social, cultural and economic aspects of the vote (Balderas, 2012).

While studies about democracy have predominated in Latin America's electoral geography (Medús, 1997), over the last twenty years there has been a proliferation of literature that goes beyond the traditional positive approaches and quantitative looks at the object of the study, superimposing holistic 
perspectives (Sonnleitner, 2005) with territorial perspectives and characterizations (Sonnleitner, 2007, 2013; Monzón, 2009; Pinto, 2016; Bosque and Buzai, 2017), that surpass the positivism that has dominated the discipline since the middle of the 20th century (Lazarsfeld and Berelson; 1962; Lazarsfeld and Elihuz, 1955) and posit new territorial outlooks (Cox, 1969), especially in relation to spatial models such as those suggested, among many, by Flint and Taylor (2002).

Another perspective, if fitting, closer to the Colombia reality might emphasize factors that may, for example, influence abstentionism, such as was posited by, among others, Benny Geys (2006), when he discusses the different models that explain electoral abstentionism, addressing the type of voters, their socioeconomic conditions and influence of the strategic vote.

The aforementioned because in Colombia, for instance, the Peace Agreement plebiscite and presidential elections demonstrated abstentionism levels of $62 \%$ and $53 \%$, respectively, which beckon to be understood in a particular key, in spatial terms and without avoiding the particular historical, social, cultural and symbolic aspects that take place in each region (Horbath, 2004).

Studies of electoral geography in Colombia have not necessarily been a prolific object of study. In any event, it is worth mentioning in the first place the Atlas of Elections in Colombia, which between 1974 and 2002 provided an electoral analysis of how the vote spread throughout the various presidential elections, including some of the factors that condition electoral behavior, as noted by Losada et al. (2004). Losada (1978) also stated that Colombia might have been the precursor of electoral geography studies upon an analysis of the relationship between geographical scales and types of election. Moreover, Dávila's (1990) contributions focused on the presidential vote, and in particular, on the relation between municipal order and the two-party system.

One perspective that has prevailed in recent years has to do with studies of department, municipality and even district cases. Thus Jácome (2012), for example, analyzes the pattern of electoral behavior in municipal elections in Bogotá, and concretely, in localities such as Teusaquillo or La Candelaria, to thereby understand the relation between the socioeconomic level and voting pattern. Mora (2010), extended his work to understand the relation between electoral patterns in various municipalities of Cundinamarca and some of the most relevant aspects of the political culture. This has been applied by Rodriguez (2005), among others, in municipal and departmental elections in Bolivar.

Perhaps with regard to the particular relation between violence and vote, one of the most outstanding and noteworthy works is one by Misión de Observación Electoral - MOE - (the Electoral Observation Mission), which completed an interesting project in 2016 showcasing an electoral risk map that presented the results of the plebiscite for the Peace Agreement with the FARC-EP, with electoral risk maps due to the territorial entrenchment and presence not only of the guerrillas, but also of criminal bands that evolved from the paramilitaries, for a period that covered 1996 to 2011.

Another similarly noteworthy work is that by González (2017), an original depiction of an analysis regarding the arguments yielded by the proponents of the "no" vote. In the electoral geography analysis he includes a look at the argumentation and manipulation, with special emphasis on a review of social media networks. This has also been addressed by others such as Magallón (2016) and Restrepo and Ramírez (2016).

In any case, there is still a prolific and potential field of study that integrates electoral geography with the relationship between direct and structural violence pertaining to the conflict. On the latter there is an interesting bibliography in the works of Echandía (2006; 2010), Salas (2010; 2015) and Rios $(2016 ; 2018)$ that shows the close relationship between the spatial dynamics of guerrilla and paramilitary activism and structural violence, so that in integrating these perspectives with an electoral geography analysis might serve to understand voting patterns and political and electoral behavior in Colombia.

This is something that has been theorized by Horbath (20115), among others, when he posits how manipulating and buying votes is brought to the elections, feeding off the poverty and inequality; on the basis of traditional political strategies that enable maintaining the status quo in the political arena, and how a weak electoral system drives away the reality of social justice from the perception of the common voter. In fact, Gutiérrez (2014) has inquired how instruments such as the privatization of security, inequality and absence of 
land ownership rights in Colombia have affected electoral behavior; while Hoskin and Pachón (2008) have centered on the direct influence of armed activism by paramilitary groups, drug traffickers and guerrillas. Finally, and in the context of events that have transpired in recent years, it is important to mention the contributions of authors like Gallego (2018), Liendo and Braithwaite (2018), and Weintraub et al. (2017).

\section{Reviewing the vulnerability map in Colombia, 2012-2015}

As stated earlier, while not all departments and regions in Colombia have been affected in the same measure, as several authors have recognized, including González (2012:2014), Rodríguez Cuadros (2015) and Bechara (2012), Colombia bears deep scars caused by the violence. In fact, Ríos (2017) noted how $82 \%$ of the municipalities with the most violence and $64 \%$ with the highest poverty had mobilized on behalf of the plebiscite in October 2016.

Based on that, and as expected, one of the pivotal elements of the Peace Agreement centered on places with the highest levels of vulnerability, which are known as PDET sites, indicating Planes de Desarrollo con Enfoque Territorial (Development Plans with a Territorial Focus). It seems that from this perspective, priority must be given to the municipalities as well as institutional and social capacities, with the aim of formalizing, driving and consolidating their productive capacity, increased government presence, and future sustainability that must uphold a peace building process (Ríos, 2017).

All of this becomes indispensable because it mainly deals with peripheral, coca farming, border territories lacking institutionality, with very strong ties to direct violence. From a departmental and comparative perspective, this has perfectly mirrored the indicator of territorial vulnerability developed by the National Planning Department (2015), which as shown in many other studies (Salas, 2015; Ríos, 2017), shows a positive and significant correspondence between said territorial vulnerability and the concurrence of armed actors, especially FARC-EP and ELN.

After the first agreement signed between the Colombian government and FARC-EP guerrillas, combats between the guerrilla and the armed forces dropped significantly as of August 26,
2012 in many municipalities around the country. In fact, according to the Peace and Reconciliation Foundation (2015, p. 5), the intensity of the confrontation decreased by up to $40 \%$ from 2013 to 2014, not a negligible figure when compared to the over 800 unilateral actions undertaken by the FARC-EP just in 2012 (Ríos, 2017).

In 2014 a total of 1,349 former FARC-EP combatants demobilized in territories with deeply rooted guerrilla affiliations, including southern Tolima and northern Huila (Peace and Reconciliation Foundation, 2015, p. 22). Similarly, during the five truces that took place while negotiations were conducted in Havana, the FARC-EP fulfilled 98\% of their agreement. Illegal actions occurred only in isolated regions, always in the most remote departments with the highest levels of territorial vulnerability. This is where the 242 municipalities are located, which in 2014 still claimed FARC-EP presence, while 99 of them had ELN presence, 60 of them coinciding with the FARC-EP (Peace and Reconciliation Foundation, 2015, p. 7).

According to Figure 1, the departments of Antioquia and Bolivar, the Pacific coastal region, the southwestern corridor and some areas in the northeast are settings with an extremely high correlation between guerrilla violence and territorial vulnerability. Some of the departments with the highest levels of structural violence include Nariño, Putumayo, Caquetá, Cauca, Valle del Cauca and Vichada. Their reality has little to do with central departments like Cundinamarca, Santander, Meta and Caldas, among others (National Planning Department, 2015).

Early last decade a central-peripheral fracture consolidated that would allow the government to justify the importance of solidifying their efforts in those scenarios in terms of investment, the productive framework, legal security and institutional strengthening. To this day, those needs are still unmet and have been unraveled by decades of armed violence.

As recognized by Salas (2016b) and the Office of the Public Defender (2015), this situation crosses over to other settings, in many cases mostly forgotten regions like Córdoba, Bolivar and Chocó, which are afflicted by particular problems such as illegal mining (Massé and Le Billon, 2017), dispossession of lands, forced displacement and a concentration of rural people in conditions of extreme poverty (Rojas, 2016). 


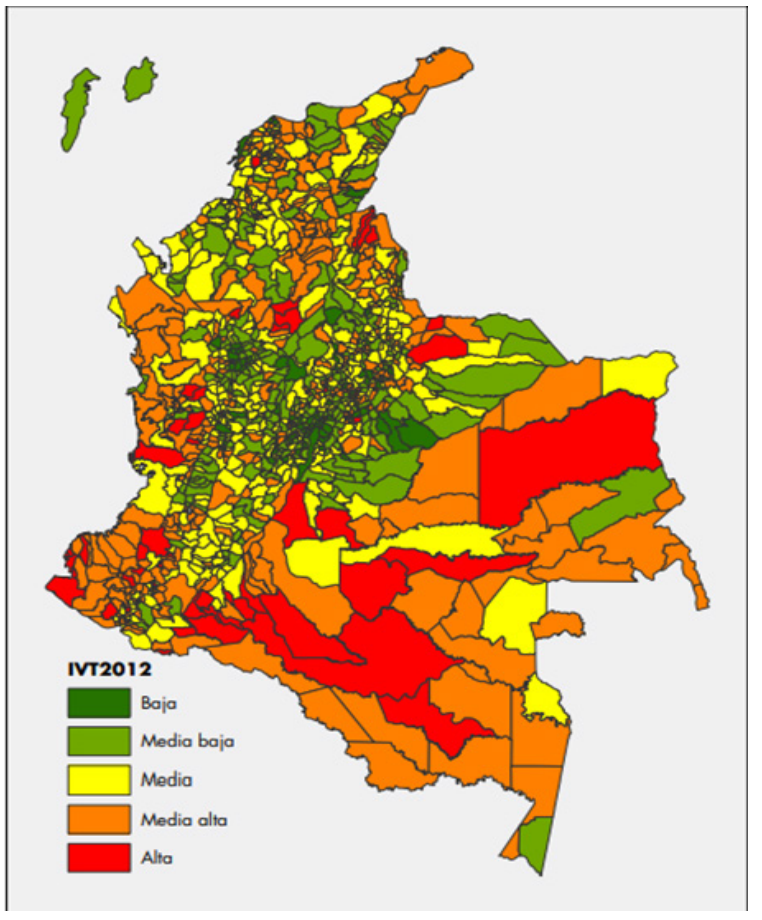

Figure 1. Index of Territorial Vulnerability Map (2012) Source: National Planning Department.

\section{Reviewing the electoral participation map for the Peace Agreement referendum signed with the FARC-EP}

The government of Juan Manuel Santos submitted the agreement signed between his Executive Office and the FARC-EP guerrillas to a plebiscite. This process meant taking unnecessary risks with the president's popularity, which at that time was below $30 \%$. Moreover, highly inflated surveys favored the agreement, alleging support of almost $70 \%$ which pointed to a favorable vote; and in addition to this, a lack of knowledge of what the Agreement entailed, plus the spectacle of the signing held one week before the plebiscite was conducted.

Because of all this, as well as a campaign strongly tainted by media manipulation and simplistic clichés that posited a fervent opposition to the Agreement, insisting that Colombia would become the next Venezuela or that the gender ideology contained in the Agreement would infringe on the traditional Colombian sense of family, the "no" to the Agreement with the FARC-EP ultimately prevailed by a tight margin of 53,000 votes. It is impossible to overlook the recourse of inadequate surveys, which clearly ended up overestimating the opinions in large cities as well in some in some

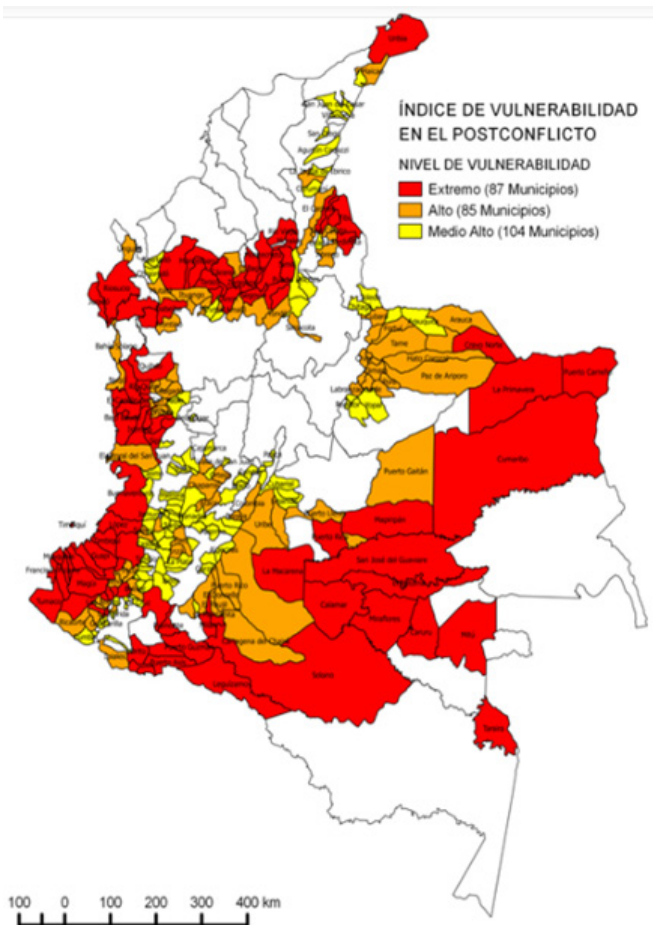

Figure 2. Index of Vulnerability Map in the Post Conflict (2015)

Source: Peace and Reconciliation Foundation (2015, p.61)

smaller towns (Basset, 2018, p. 244).

As observed in Figure 3, departments shaded in green represent those where the vote favorable to the Peace Agreement prevailed. It could be said that at least there is a possible correlation between border departments, which have peripheral characteristics and are more affected by direct and structural violence (Ríos, 2017) and a position of stronger commitment to closing the armed conflict with the FARC-EP guerrilla in a negotiated manner.

Expressed in different terms, central enclaves without a guerrilla presence for a number of years and/or favored by the Democratic Security Policy and Plan Colombia would have demonstrated a stronger rejection to a negotiated solution in this instance, underscoring the hypothesis of being distant from the violence which is maintained by Rincón (2016) and Álvarez and Garzón (2018), among others.

In any case, honing in on the analysis and beyond the fact that in departments like Caldas (57.09\%), Cundinamarca (56.52\%), Huila (60.77\%), Meta (63.58\%), Quindío (69.13\%), Risaralda (55.69\%), Santander (55.64\%) and Tolima (59.71\%) the Peace Agreement was roundly rejected, it is 


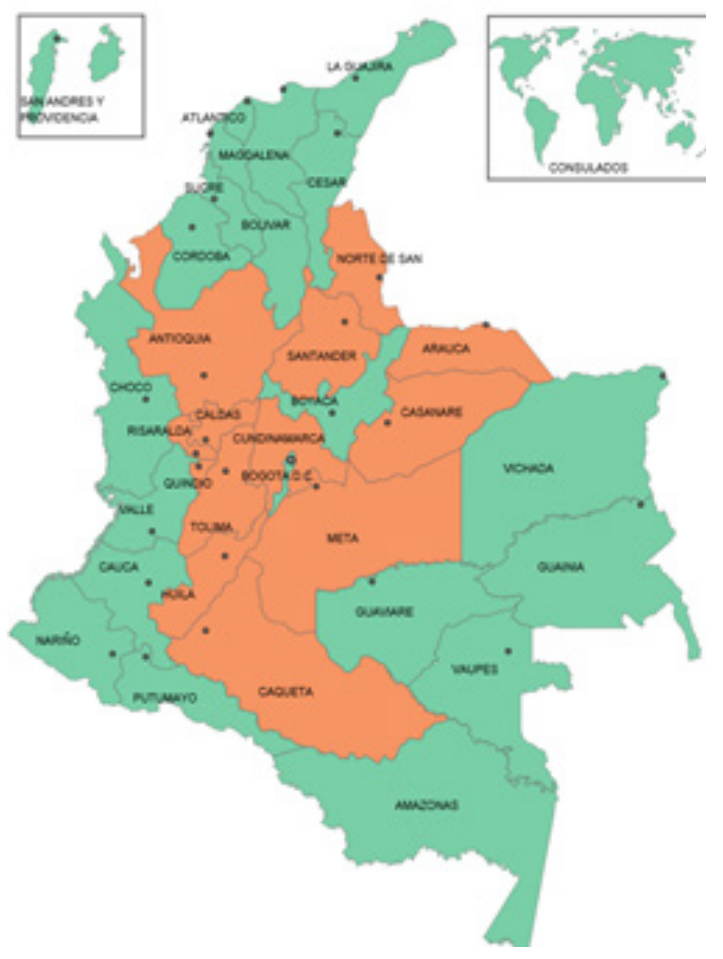

Figure 3. Results of the Peace Agreement plebiscite by departments, 2016. Green depicts in favor of the Peace Agreement with the FARC-EP.

Source: National Civil Registry (s.p.).

obvious that in peripheral settings like Norte de Santander (63.92\%) and Casanare (71.14\%), with very high levels of disapproval for the Agreement, and similar to what happened in Central America, there was a direct influence of having been victimized by kidnappings, extortion and violence for decades by the guerrilla.

At any rate, it is important to be careful with methodologies and analyses that have to be developed in the field of political and electoral geography, among others, because at the same time, in places where the FARC-EP was a hegemonic actor for decades were where in general terms there was a greater mobilization in favor of the Agreement. This mobilization also prevailed in 21 of the 32 Colombian departments, very significantly in Chocó (79.76\%), Vaupés (78.05\%), Cauca (67.39\%) Putumayo (65.50\%) and Nariño (64.81\%). Specifically, departments with the worst conditions in terms of multi-dimensional poverty, income inequality and unmet basic needs indicators (DANE, 2016). These are elements inherent to the structural violence which would also include a marked coca-growing footprint, as half of all coca crops grown in Colombia are concentrated in just three departments; Nariño (42.627Ha), Putumayo (25.162Ha) and Cauca (12.595Ha).

Thus, and according to Basset (2018), it would be fitting to accept the hypothesis of a sort of voting for peace in the territories most affected by the violence from the armed conflict, because those municipalities that reported the greatest FARCEP presence participated with $56 \%$ favoring the Agreement. In turn, areas with more ELN presence voted yes with $57 \%$ support. To a lesser degree this happened in municipalities with strongly entrenched criminal bands (51.1\%), in contrast with the $65.9 \%$ support for the Agreement obtained in the other municipalities targeted by the Development Plans with a Territorial Focus, as well as in other enclaves where there were more displacements in 2016 that reported favorable support for the Agreement in excess of $55 \%$. The relative weight of the rural/ urban divide, the popularity of Juan Manuel Santos and the manipulating influence of parties that sabotaged the peace process must at the very least be taken into consideration in all these cases (Bergquist, 2017).

Ultimately, and beyond any particular aspects which will certainly be addressed and satisfied in the future thanks to political and social research, the truth is that everything indicates the need to take into consideration a correlation between the territories that reported more FARCEP guerrilla actions, resulting from their historical entrenchment, and the opportunities and favorability for a framework to overcome armed violence and build peace. Thus, understanding the plebiscite as an enabler mechanism for the citizenry to express their position on the issues negotiated with the FARC-EP guerrillas, in conclusion it must be considered that those who lived closest to the dynamics of the direct violence, at least in recent years, are those who manifested a greater degree of favorability thereto.

\section{Reviewing the political-electoral participation map in the 2018 presidential elections}

Although Ivan Duque's successful bid in the second round of presidential elections in 2018 resulted from the support and backing of the Andean corridor and the country's central-southern region, giving him nearly ten million votes, it is not wise to ignore 
the important support received by progressive candidate Gustavo Petro, who earned over eight million votes.

In some departments that border Venezuela such as La Guajira, Cesar, Norte de Santander and Arauca, Uribism certainly prevailed, using the current situation in Venezuela as a perfect instrument to stress the political sense and direction it offered Colombia at that time. Morphing Gustavo Petro into Nicolás Maduro and taking advantage of being on the border with Venezuela, Uribism played an easy match in that part of the country. So it used campaign slogans like "I don't want to live like a Venezuelan" and launched the presidential campaign in a Venezuelan supermarket, much like Marta Lucía Ramírez did. It used the Andean neighbor to leverage its fear campaign, adding other elements that really shake up Colombia, such as Gustavo Petro's past as a member of the M-19 guerrilla, and fixated on the term "Castro-chavism". With more intensity after the second round, the majority of conservatives surrounded Iván Duque, including the Conservative Party, the Liberal Party, the U Party and Radical Change, plus the evangelical churches and the MIRA Party, as well as famous personalities the likes of Alejandro Ordóñez, Juan Carlos Pinzón and Viviane Morales, and business associations such as the National Coffee-Growers Association, Asobancaria and Servientrega, to name a few. Sensu contrario, Gustavo Petro received the support of Claudia López, his Vice-president was Sergio Fajardo in the first round; Antanas Mockus, senator, and other outstanding individuals such as Ingrid Betancourt, Clara López, Antonio Navarro and Iván Cepeda, all of whom agreed in pointing out that Petro was the only one that could guarantee the Peace Agreement with the FARC-EP. This was shared with important associations, including the Colombian Federation of Education Workers (FECODE), the National Indigenous Organization of Colombia (ONIC), the Central Workers Union (CUT), and support from international academics like Thomas Piketty, Slavoj Žižek and John Maxwell.

Just as the plebiscite showed which regions supported the Peace Agreement, a territorial dynamic for the vote was evident in elections for the National Congress held on March 11, as in previous presidential elections. Some considerations are presented below, paying special attention to the second round of presidential elections where the discourse and political position in favor of or against the Peace Agreement can be best observed.

\section{The political-territorial trend in central departments}

Table 1 below was prepared with a strict classification determined by each department's geographical location. Added to this are other aspects such as the territorial vulnerability index (TVI), which is understood as "insecurity found in communities, families or individuals as a result of the impact caused by some type of economic-social event" (Pizarro, 2001, p.11). To that end, TVI studies conducted by the National Planning Department were taken into consideration to learn about the possible connection between direct violence and structural violence based on six weighted variables: 1) humanitarian assistance, 2) security, 3) justice, 4) social development, 5) economic development, and 6) governance in terms of fiscal capacity (National Planning Department, 2015, p.8).

The second aspect addressed has to do with the human development index (HDI) which is calculated on the basis of variables such as per capita GDP, life expectancy and education (UNDP, 2011). In this manner, it would be easy to understand that

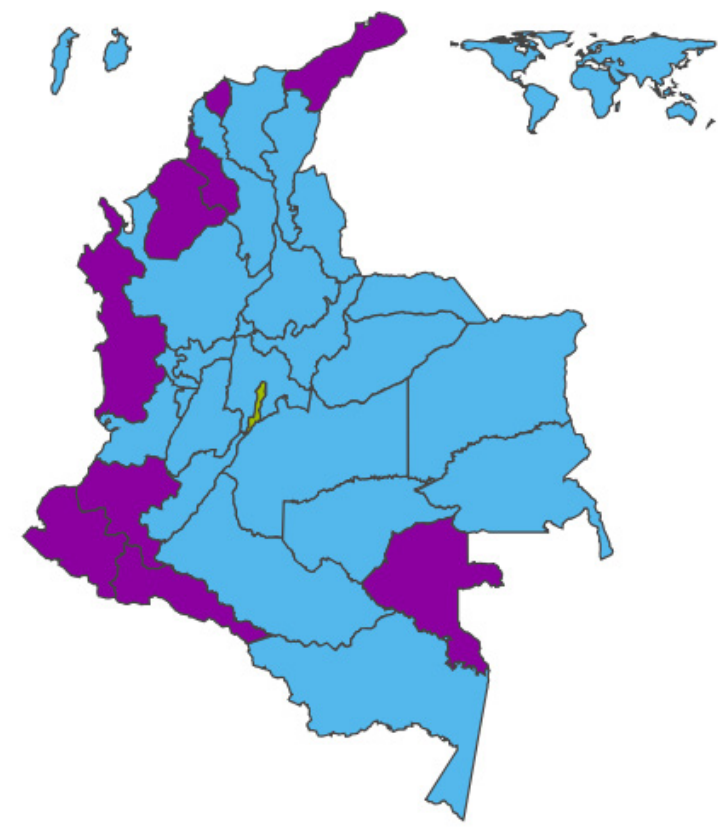

Figure 4. Result of the presidential elections in the second round, 2018.

Source: National Civil Registry (s.p.). 
there is an inversely proportional relation between inequality and human development. In other words, as a department or municipality displays greater inequality, its human development index will be lower (UNDP, 2011, P.57).

In examining the results, some notable changes are evident in the voting outcome, mainly in the second round, in favor of Iván Duque as related to the Peace Agreement plebiscite. For instance, departments located in the coffee belt, and in general, in the Andean region, displayed a marked favoritism for Iván Duque, five points on average above the vote against the Peace Agreement in 2016,

Something remarkable, for example, in departments like Antioquia (72.53\%), Caldas (65.67\%), Quindío (62.76), Risaralda (61.57\%) and a considerable area in north Tolima (65.89\%). While in all these there is a close correlation between presidential preference and the position on negotiations with the FARC-EP, on the other hand it is worth mentioning that for the most part these are departments with a medium or low TVI impact, which minimizes things like structural violence.

In that regard, the only exception would be the city of Bogotá, which went opposite to the department of Cundinamarca, despite the fact that both settings share a very low TVI and one of the highest HDI in the country. So while approval for the plebiscite in Bogotá was at 50.08\% in favor, most of the municipalities in Cundinamarca voted against it and the Uribista trend, something that occurred similarly in Boyacá with regard to the even more progressive position of some of its major cities, like Villa de Leyva with 51.79\% and the capital city, Tunja with $56.62 \%$.

\section{The political-territorial trend in peripheral departments}

Things were very different in the peripheral departments, which represent twenty-two of the thirty-two Colombian departments. There they showed clear favoritism for the Peace Agreement, and also for Gustavo Petro's candidacy. In fact, eight of the departments took both of those positions.

Except for Bogotá, the progressive candidate for "Colombia Humana" won the peripheral departments located in the southwestern region of Colombia, including Cauca (65\%), Nariño (63.85\%) and Putumayo (69.63\%); as well as in the Pacific

Table 1.

Central Departments. Classification between the territorial vulnerability index (TVI), human development index (HDI), percentage of votes in the 2016 plebiscite and percentage of votes in the 2018 second presidential round

\begin{tabular}{lllllll}
\hline Departments & TVI Rating & HDI & $\begin{array}{l}\text { Plebiscite } \\
\text { vote }\end{array}$ & \% & $\begin{array}{l}\text { Second presidential } \\
\text { round vote }\end{array}$ & $\%$ \\
\hline Antioquia & Medium-low & 0.849 & NO & 62 & Iván Duque & 72.53 \\
\hline Bogotá & Low & 0.904 & YES & 56.07 & Gustavo Petro & 53.35 \\
\hline Boyacá & Medium-low & 0.842 & YES & 50.08 & Iván Duque & 54.81 \\
\hline Caldas & Medium & 0.828 & NO & 57.09 & Iván Duque & 65.67 \\
\hline Cundinamarca & Low & 0.837 & NO & 56.52 & Iván Duque & 56.48 \\
\hline Huila & Medium & 0.807 & NO & 60.77 & Iván Duque & 64.71 \\
\hline Meta & Medium & 0.822 & NO & 63.58 & Iván Duque & 63.95 \\
\hline Guindío & Medium-low & 0.832 & NO & 60.13 & Iván Duque & 62.76 \\
\hline Risaralda & Medium-low & 0.839 & NO & 55.69 & Iván Duque & 61.57 \\
\hline Santander & Medium-low & 0.879 & NO & 55.64 & Iván Duque & 60.30 \\
\hline Tolima & Medium-low & 0.804 & NO & 59.71 & Iván Duque & 65.89 \\
\hline
\end{tabular}

Source: Prepared by author based on data from the National Registry, National Planning Department and the United Nations. 
region departments like Chocó (58.82\%) and Valle del Cauca (51.76\%) and others like Vaupés (59.56\%), and in the northwestern corner as was seen in Atlántico (54.96\%) and Sucre (50.39\%). One common vector, especially with regard to the southwestern region of Colombia, and perhaps reaching the entire Pacific coast, would be crucial impact of both direct violence (Salas, 2010; 2015; Ríos, 2016; 2017) and structural violence (DNP, 2016; 2017), which translates, among other things, into an absence by the Government, multidimensional poverty, greater inequality in terms of income and/or concentration of land, repeated killings of social leaders, in addition to other important lacking in terms of unmet needs.

There are other significant nuances at work here that should be more meticulously addressed. For instance, in departments like Arauca, Norte de Santander and Caquetá, despite a large presence of armed groups and high levels of coca crops (with the exception of Arauca), support for Duque shot up to fifteen percentage points on average if compared with the voting against the Peace Agreement with the FARC-EP. In this way, the condition of sharing a border with Venezuela (again), or the fact that in the conservative vote prevailed in Caquetá, if only for the differentiating factor of the capital city of Florencia, seem to invite reservation and a more meticulous analysis.

On the other hand, important differences should be noted between the northwestern border and the southeast, both between the regions themselves and the mobilization for the plebiscite and the presidential election. So while Amazonas (56.64\%), Bolivar (60.23\%), Córdoba (60.73\%), La Guajira (61.14\%) and Magdalena (60.53\%) voted overwhelmingly in favor of the Peace Agreement, at the same time the Uribista candidate was victorious in the presidential elections, albeit with a smaller margin of support than in the Colombian Andean corridor.

In turn, Antioquia emerged as the department with the strongest support for conservatism, despite being significantly impacted by the internal armed conflict, and where Iván Duque would not only prevail widely, but only 29 of its 125 municipalities voted for the Peace Agreement, with notable exceptions in municipalities such as Ituango, Segovia, Murindó, Chigorodó and San José de Apartadó. The dynamics in Chocó were also in the opposite direction, being one of the departments with the strongest support for the vote for peace hypothesis, and where support for Gustavo Petro and the Peace Agreement was especially relevant in municipalities such as Bojayá and Vigía el Fuerte.

\section{Conclusions}

As part of the brief description reported herein, it is important, as the basis of a geographical-electoral theory, to first address an eventual relation between the people's political and electoral behavior, and the relation of the territory both with direct violence and with the desire of overcoming it. Therefore, and in the absence of deeper research, it is possible to accept the concurrence that in certain settings across the country there is a position supportive of the political and ideological options that result in a structural transformation of violence, and the assumption of a scenario of positive and transforming peace, as described by Johan Galtung, which are closer to supporting the Peace Agreement and Gustavo Petro than the line represented by Iván Duque.

Thus it becomes clear that the departments and municipalities with the highest index of territorial vulnerability were also, for the most part, the regions that said "yes to peace". This fact leads to observe a close relationship between direct violence and structural violence, as in the case of departments such as Nariño, Putumayo, Valle del Cauca, Cauca, Chocó, and a large swath of Caquetá. In contrast, areas that benefitted from the Democratic Security Policy and Plan Colombia include departments such as Cundinamarca, Meta, the coffee belt and Antioquia.

Based on all of the above, only 13 of the 32 Colombian departments actually voted against the Peace Agreement, which are primarily in the most central enclaves in the country, Similarly, regarding voter preference in the electoral contests, other than the paradoxical case of Bogotá, in settings like the Pacific coastal region there is less support for Duque, and then there is the influence (beyond the peace/violence duality and other issues that triggered electoral support) resulting from the predominantly conservative political culture that characterizes the country. That is, the threat of what is crudely called "gender ideology", or the risk of "Castrochavisizing" Colombia, emulating the political and social processes of Cuba and Venezuela, which far from any reality, could lead to deactivating the electoral mobilization for reasons 
Table 2.

Peripheral Departments. Classification between the territorial vulnerability index (TVI), human development index (HDI), percentage of the vote in the 2016 plebiscite and percentage of the vote in the 2018 second presidential round.

\begin{tabular}{|c|c|c|c|c|c|c|}
\hline Departments & $\begin{array}{l}\text { Vulnerability } \\
\text { rating }\end{array}$ & HDI & $\begin{array}{l}\text { Plebiscite } \\
\text { voting }\end{array}$ & $\%$ & $\begin{array}{l}\text { Voting second } \\
\text { presidential round }\end{array}$ & $\%$ \\
\hline Atlántico & Medium-high & 0.835 & YES & 60.53 & Gustavo Petro & 54.96 \\
\hline Cauca & Medium-high & 0.782 & YES & 67.39 & Gustavo Petro & 65 \\
\hline Chocó & Medium-high & 0.731 & YES & 79.76 & Gustavo Petro & 58.82 \\
\hline Nariño & Medium-high & 0.773 & YES & 64.81 & Gustavo Petro & 63.85 \\
\hline Putumayo & Medium-high & 0.759 & YES & 65.50 & Gustavo Petro & 69.63 \\
\hline Sucre & Medium & 0.775 & YES & 61.88 & Gustavo Petro & 50.39 \\
\hline Valle del Cauca & Medium-high & 0.861 & YES & 52.44 & Gustavo Petro & 51.76 \\
\hline Vaupés & Medium-high & 0.768 & YES & 78.05 & Gustavo Petro & 59.56 \\
\hline Amazonas & Medium-high & 0.768 & YES & 56.64 & Iván Duque & 50.42 \\
\hline Arauca & Medium & 0.804 & NO & 51.37 & Iván Duque & 64.94 \\
\hline Bolívar & Medium-low & 0.823 & YES & 60.23 & Iván Duque & 51.18 \\
\hline Caquetá & Medium-high & 0.752 & NO & 53.04 & Iván Duque & 62.17 \\
\hline Casanare & Medium-low & 0.867 & NO & 71.14 & Iván Duque & 72.78 \\
\hline Cesar & Medium-low & 0.81 & YES & 50.66 & Iván Duque & 54.24 \\
\hline Córdoba & Medium-low & 0.798 & YES & 60.73 & Iván Duque & 50.16 \\
\hline Guainía & Medium-high & 0.768 & YES & 55.52 & Iván Duque & 57.06 \\
\hline Guaviare & Medium-high & 0.768 & YES & 52.86 & Iván Duque & 58.35 \\
\hline La Guajira & Medium-high & 0.691 & YES & 61.14 & Iván Duque & 54.88 \\
\hline Magdalena & Medium & 0.785 & YES & 60.53 & Iván Duque & 51.83 \\
\hline Norte de Santander & Medium-high & 0.799 & NO & 63.92 & Iván Duque & 77.89 \\
\hline $\begin{array}{l}\text { San Andrés y } \\
\text { Providencia }\end{array}$ & Medium-low & 0.834 & YES & 55.01 & Iván Duque & 61.20 \\
\hline Vichada & High & 0.768 & YES & 50.66 & Iván Duque & 63.94 \\
\hline
\end{tabular}

Source: Prepared by author based on data from the National Registry, National Planning Department and the United Nations.

strictly related to the armed conflict.

In conclusion, and while this paper does not shed any conclusive results or closed hypotheses, it still serves to identify possible lines of research that could optimize the geo-political explanation of how the armed conflict and its demise has articulated a type of political and electoral response in certain settings across Colombia.

\section{References}

Agnew, J. (1987). Place and Politics. Nueva York: Harper Collins.

Balderas, R. (2012). Génesis de la geografía electoral. Espacialidades. Revista de temas contemporáneos sobre lugares, política y cultura, 2 (1), pp. 81-95.

Basset, Y. (2018). Claves del rechazo del plebiscito para 
la paz en Colombia. Estudios Políticos, 52, pp 241-265.

Bechara, E. (2012) ¿Prolongación sin solución? Perspectivas sobre la guerra y la paz en Colombia. Bogotá: Universidad Externado.

Bergquist, C. (2017). La izquierda colombiana: un pasado paradójico, ¿un futuro promisorio? Anuario Colombiano de Historia Social y de la Cultura, 44 (2), pp. 263-299.

Bosque, J and Buzai, G. (2017). Geografía Electoral de la Ciudad Autónoma de Buenos Aires, 2015. Elecciones a Jefe de Gobierno municipal ya Presidente de la República Argentina. Persona y Sociedad, 31 (1), pp. 48-73

Bussi, M. (1998). Eléments de géographie électorale à travers l'exemple de la France de l'Ouest, Rouen: Publications de l'Université de Rouen.

Cox, K. R. (1969). The voting decision in spatial context. Progress in Geography, 1, pp. 40-53.

Dávila, A. (1990). Proceso electoral y democracia en Colombia: las elecciones de marzo y mayo de 1990. Revista Mexicana de Sociología, 52 (4), pp. 99-125

Departamento Nacional de Planeación (2015). Índice de Vulnerabilidad Territorial: Resultados 20082012. Bogotá.

National Planning Department (2019). Monitoring Indicators. [Online] Available at: https:// www.dnp.gov.co/DNP/sistema-integrado-degestion/Paginas/indicadores-de-seguimiento. aspx [Checked 27 Feb. 2019].

Echandia C. et al. (2010) Colombia: Estado del conflicto armado al final de la Administración de Álvaro Uribe. In H. Mathieu and C. Niño (eds.) Seguridad regional en América Latina. Anuario 2010. Bogotá: Friedrich Ebert Stiftung.

Echandía, C. (2006). Dos décadas de escalamiento del conflicto armado en Colombia 1986- 2006. Bogotá: Universidad Externado.

Elihuz, K. y Lazarsfeld, L. (1955). Personal Influence. The Part Played by People in the Flow of Mass Communications. Nueva York: Free Press.

Fiorina, M. (1981). Retrospective Voting in American National Elections. New Haven: Yale University Press.

Fundación Paz y Reconciliación (2015). Lo que hemos ganado. Bogotá.

Gallego, J. (2018) Civil conflict and voting behavior: Evidence from Colombia. Conflict Management and Peace Science, 35 (6), pp. 601-621

Geys, B. (2006). Rational' Theories of Voter Turnout: A Review. Political Studies Review, 49 (4), pp. 6-35

Goguel, F. (1951). Esquisse d'un Bilan de la Sociologie Electorale Française. Revue Française De Science Politique, 1 (3), 277-297.
González M. (2017). La posverdad en el Plebiscito por la paz en Colombia. Nueva Sociedad, 269, pp. $115-128$

González, F. et al. (2012). Conflicto y territorio en el oriente colombiano. Bogotá: CINEP.

González, F. et al. (2014). Territorio y conflicto en la Costa Caribe. Bogotá: CINEP.

Horbath, J. (2004). Pobreza y elecciones en Colombia Algunos hallazgos para reflexionar. Estudios sobre Estado y Sociedad, 10 (29), pp. 192- 232

Jácome, J. (2012) Patrones espaciales en las elecciones locales del 2007 en Bogotá, Colombia. Cuadernos de geografía, 22 (1), pp. 141-168

Johnston, R. et al. (1987). Diccionario de geografia humana. Madrid: Alianza

Lazarsfeld, P. and Berelson, B. (1962). El pueblo elige. Estudio del proceso de formación del voto durante una campaña presidencial. Buenos Aires: Ediciones3.

Liendo, N. y Braithwaite, J. (2018). Determinants of Colombian attitudes toward the peace process. Conflict Management and Peace Science, 35 (6), pp. 622-636.

Lois, M. (2010). Estructuración y espacio: la política del lugar. Geopolítica(s), 1 (2), 207-231.

Losada, R. (1978). El significado político de las elecciones de 1978 en Colombia. Bogotá: Fedesarrollo.

Losada, R. et al. (2004). Atlas sobre las elecciones presidenciales de Colombia 1974-2002. Bogotá: Pontificia Universidad Javeriana.

Magallón, C. (2016). La paz en Colombia: decepción, controversia y esperanza. Revista Cultura y Paz, 22 (70), pp. 4-10.

Massé, F. y Le Billon, P. (2017). Gold mining in Colombia, post-war crime and the peace agreement with the FARC. Third World Thematics: A TWQ Journal, 3 (1), pp. 116-134.

Medús, N. (1997). Los estudios electorales en la geografía. Huellas, 1, pp. 9-25.

Monzón, N. (2009). Geografía electoral. Consideraciones teóricas para el caso argentino. Cuadernos de geografia, 18, pp. 119-128

Mora E. (2010). Comportamiento electoral en el municipio de Zipaquirá en la elección popular de alcaldes durante el periodo 1988 a 2007. Bogotá: Universidad Javeriana.

Pinto, R. (2016). Comportamiento electoral: metodologías y agendas de investigación en Bolivia. Temas Sociales, 39, pp. 62-80

UNDP (2011). Colombia rural 2011. Razones para la Esperanza. Bogotá.

Restrepo, L. and Ramírez, S. (2016). Colombia: sorpresas y sobresaltos de la paz. Nueva Sociedad, 266, pp. 129- 139

Registraduría Civil. (2019). Registraduría Nacional del 
Estado Civil -. [Online] Registraduría Nacional del Estado Civil. Available at: https://www. registraduria.gov.co/?page=plebiscito_2016 [Checked 27 Feb. 2019].

Registraduría Civil. (2019). Registraduría Nacional del Estado Civil -. [Online] Registraduría Nacional del Estado Civil. Available at: https:// www.registraduria.gov.co/-Historico-deResultados,3635-.html [Checked 27 Feb. 2019].

Ríos, J. (2016). Dinámicas de la violencia guerrillera en Colombia. Revista de Ciencias Sociales, 22 (3), pp. 84-103.

Ríos, J. (2016). La periferialización del conflicto colombiano, 2002-2014. Geopolítica(s) 7 (2), pp. 251-275.

Ríos, J. and Gago, E. (2018). Realidades y desafíos de la paz territorial en Colombia. Papers. Revista de Sociología, 103 (2), pp. 281-302

Rodríguez Cuadros, J. D. (2015). Génesis, actores y dinámicas de la violencia política en el Pacífico nariñense. Bogotá: CINEP.

Rodríguez, A. (2005). Análisis sobre el comportamiento electoral en el departamento de Bolívar durante el periodo 1991-2003, elección de alcaldes y gobernadores. Bogotá: Universidad Javeriana.

Rojas, J. (2016). Postacuerdo y gestión territorial en Colombia. Bitácora, 26, pp. 135-146

Salas, L. G. (2010). Corredores y territorios del conflicto armado colombiano: una prioridad en la geopolítica de los actores armados. Perspectiva Geográfica, 15, pp. 9- 36.

Salas, L. G. (2015). Lógicas territoriales y relaciones de poder en el espacio de los actores armados: un aporte desde la geografía política al estudio de la violencia y el conflicto armado en Colombia, 1990-2012. Cuadernos de Geografía, 24 (1), pp. 157-172.
Salas, L. G. (2016). Conflicto armado y configuración territorial: elementos para la consolidación de la paz en Colombia. Bitácora, 26, pp. 45-57

Sánchez, G. (1987). Colombia: violencia y democracia. Comisión de Estudios para la Violencia. Bogotá: La Carreta.

Siegfried, A. (1913). Tableau politique de la France de l'Ouest. París: Librairie Armand Colin

Sonnleitner, W. (2005). Territorios y fronteras del voto: hacia una agenda de geografía electoral para Centroamérica. Trace, 48, pp. 90-108.

Sonnleitner, W. (2007). Geografia electoral, cartografia exploratoria y análisis multidimensional del voto. In A. Islas (comp.). Elecciones y geografía electoral, vol. 2, Grandes temas para un observatorio electoral ciudadano. México,D.F.: Instituto Electoral del Distrito Federal.

Sonnleitner, W. (2013). Explorando las dimensiones territoriales del comportamiento político: Reflexiones teórico-metodológicas sobre la geografía electoral, la cartografía exploratoria y los enfoques espaciales del voto. Estudios Sociológicos, 31, pp. 97-142.

Taylor, P. and Flint, C. (2002). Geografia Política. Economía-mundo, Estado-Nación y Localidad. Madrid: Trama.

Weintraub, M et al. (2017) Vote choice and legacies of violence: evidence from the 2014 Colombian presidential election. Research and Politics, 2 (2), pp. 1-8. 